\title{
Graduate Employability in the Kingdom of Saudi Arabia: A future research Agenda
}

\author{
Mohammed H Alwethainani, Zuraina Dato Mansor
}

\begin{abstract}
In recent decades, a growing body of literature has emerged to illustrate the strong pressure on education institutions to prepare graduates for the world of work. This challenge has intensified since the expansion of higher education process that reframed the policy debate and placed the smooth transition from school-to-work and the employability of graduates at the forefront of education policy. In this scenario it is imperative to analyze the research trends in this area of research. The present study examined the research articles published in this area till 2018. The data was collected using the Scopus database to analyze the research trends in this area. The study findings have clearly highlighted that majority of the research in the field of employability is conducted in developed countries and this area of study is under explored in Kingdom of Saudi Arabia. The findings also showed that the research related to the factors contributing towards Saudi graduates' employability is one area which needs to be studied.
\end{abstract}

Index Terms: Literature Review, Employability, Kingdom of Saudi Arabia, Saudization.

\section{I.INTRODUCTION}

the theory of employability can be difficult to identify however, there were many studies which suggest attributes and factors that contribute to the idea of being employable. in this section, the study discuss theories that are employed and develop a theoretical framework which explains the relationships between the variables of interest, such perceived protean career, and career building skills, personality trait and employability. additionally, the study developed model based on these theories and conceptual framework is presented. saudi arabia or kingdom of saudi arabia (ksa) is reforming its economy to keep phase with the new development of the global market. however, the kingdom's core citizen graduates are still facing with an issue like the unemployment among themselves. the tradition in this kingdom is it becomes automatic for the graduates to secure a job but this is no longer feasible due to the changing phase of the economy, contributed by the technological development and the shift in paradigm from an administrative-based to a rapidly developing and an industrialized state. However, unemployment is considered to be a worldwide growing trend and as a matter of fact, there is a growing trend towards unemployment among graduates as the worldwide issue [1]. Therefore, graduates in

Revised Manuscript Received on October 15, 2019.

Mohammed Alwethainani, Faculty of Economics and Management, University Putra Malaysia. *Corresponding author's email: wathnani@yahoo.com

Zuraina Dato Mansor, Faculty of Economics and Management, University Putra Malaysia. worldwide need to refocus their capabilities and improved their employability skills in order to meet the required skills and competencies wanted by the employers [2],[3].

\section{II.LITERATURE REVIEW}

In general, the world sees Saudi as a country which is having a relatively healthy economic due to its main source from oil revenue which accounts for $92 \%$ incomes and the prospect of non-oil growth of 4-5\% in 2015 to 2018, [4]. Saudi also enjoys comparatively lower inflation rate, and the economic growth has been above the trend, and it is sufficiently able to offer a wide range of employment opportunities to the citizen. However, the labor market is highly lopsided. The better-educated Saudis' working class is primarily employed in the public sector and most of the highly skilled and the highest paid jobs in the private sectors are held by the foreigners. The reasons for these are mentioned as the locals have the lack of employability competencies required by the private sectors [5],[6] and lack the willingness to work and the general preference for a particular job/sector [7]. Further, according to the GCC Economic Outlook Report (2014)[8], Saudis are not specializing in fields such as engineering, industrial and media: Only 12\% of the fresh Saudi's graduates were from streams that are related to media studies in 2012, whereas only $13 \%$ from engineering and science streams. A vast majority of the citizen goes to the humanities, Islamic studies and business management and administration. With regards to the composition of the labor force in according to the sectors, services sectors, technical skills jobs are mostly occupied by expatriates, while the locals occupy the administrative jobs. In the manufacturing sector, Saudis occupy just $22 \%$. While in general, in 2012, out of the total 10.6 million paid employment people of Saudi, there were $44 \%$ locals and the remaining $56 \%$ were expatriates [9

\section{III.METHODOLOGY}

The study used a systematic literature review approach to study the research trends in the field of Graduate Employability in Kingdom of Saudi Arabia. The researcher used the key word employability to search for the articles related to this area [10],[11]. The study included only the articles indexed in SCOPUS database and published till the year 2018, to understand the research trend. A total of 7868 articles related to employability was included for this study. The articles were then analyzed using the Scopus database feature of analysis search. The articles which were on

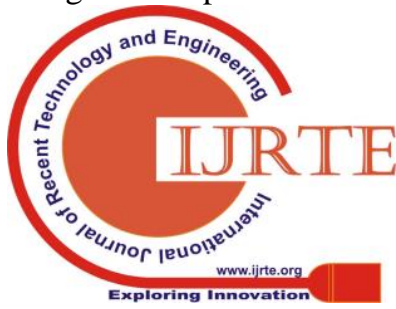


Graduate Employability in the Kingdom of Saudi Arabia: A future research Agenda

employability was further analyzed by reading the content and analyzing the area of research and their conclusions.

\section{IV.FINDINGS}

The findings from the systematic literature review was divided into mainly three criteria for analysis, firstly the country the research article was published, secondly, the subject area and the third criteria was the number of articles published. The figure 1 shows the country wise breakup of articles indexed in Scopus related to employability between the year 1929 and 2018. The analysis shows around 36\% of the articles in this research area is published in countries like United Kingdom and United States. The research related to employability is underexplored in the Middle East region. Table 1 gives the Country wise breakup of articles indexed in Scopus related to employability.

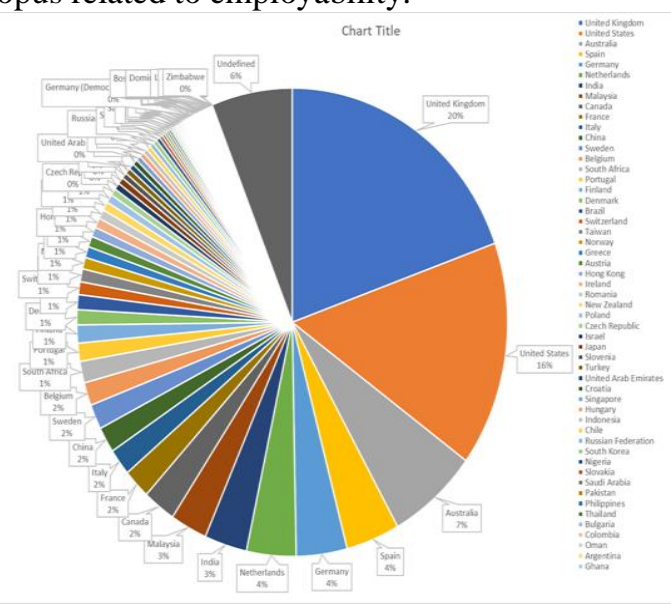

Figure 1: Country wise breakup of articles indexed in Scopus related to employability (1929 - 2018)

The country wise breakup given in the Table 1 clearly highlights the lack of studies related to employability in the Kingdom of Saudi Arabia (KSA). In more than seven decades only a total of 16 articles is published in the area of employability.

Table 1: Country wise breakup of articles indexed in Scopus related to employability.

\begin{tabular}{|c|c|}
\hline COUNTRY/TERRITORY & $\begin{array}{c}\text { No. of } \\
\text { articles }\end{array}$ \\
\hline United Kingdom & 1536 \\
\hline United States & 1223 \\
\hline Australia & 535 \\
\hline Spain & 317 \\
\hline Germany & 300 \\
\hline Netherlands & 292 \\
\hline India & 251 \\
\hline Malaysia & 218 \\
\hline Canada & 194 \\
\hline France & 161 \\
\hline Italy & 145 \\
\hline China & 140 \\
\hline Sweden & 136 \\
\hline Belgium & 125 \\
\hline South Africa & 117 \\
\hline Portugal & 99 \\
\hline
\end{tabular}

\begin{tabular}{|c|c|}
\hline Finland & 98 \\
\hline Denmark & 82 \\
\hline Brazil & 81 \\
\hline Switzerland & 70 \\
\hline Taiwan & 70 \\
\hline Norway & 63 \\
\hline Greece & 60 \\
\hline Austria & 58 \\
\hline Hong Kong & 53 \\
\hline Ireland & 53 \\
\hline Romania & 51 \\
\hline New Zealand & 48 \\
\hline Poland & 45 \\
\hline Czech Republic & 38 \\
\hline Israel & 37 \\
\hline Japan & 37 \\
\hline Slovenia & 32 \\
\hline Turkey & 32 \\
\hline United Arab Emirates & 31 \\
\hline Croatia & 30 \\
\hline Singapore & 29 \\
\hline Hungary & 27 \\
\hline Indonesia & 27 \\
\hline Chile & 25 \\
\hline Russian Federation & 25 \\
\hline South Korea & 24 \\
\hline Nigeria & 23 \\
\hline Slovakia & 19 \\
\hline Saudi Arabia & 16 \\
\hline Pakistan & 15 \\
\hline Philippines & 14 \\
\hline Thailand & 14 \\
\hline Bulgaria & 12 \\
\hline Colombia & 12 \\
\hline Oman & 11 \\
\hline Argentina & 10 \\
\hline Ghana & 10 \\
\hline Mexico & 10 \\
\hline Cyprus & 9 \\
\hline Viet Nam & 9 \\
\hline Kuwait & 8 \\
\hline Latvia & 8 \\
\hline Qatar & 8 \\
\hline Serbia & 8 \\
\hline Iran & 7 \\
\hline Kenya & 7 \\
\hline Luxembourg & 7 \\
\hline Macao & 7 \\
\hline Germany (Democratic Republic, DDR) & 6 \\
\hline $\begin{array}{l}\text { Jordan } \\
\end{array}$ & 6 \\
\hline Kazakhstan & 6 \\
\hline Lithuania & 6 \\
\hline Bangladesh & 5 \\
\hline Botswana & 5 \\
\hline Costa Rica & 5 \\
\hline Estonia & 5 \\
\hline Sri Lanka & 5 \\
\hline Uganda & \\
\hline
\end{tabular}




\begin{tabular}{|c|c|}
\hline Bahrain & 4 \\
\hline Ecuador & 4 \\
\hline Ethiopia & 4 \\
\hline Palestine & 4 \\
\hline Peru & 4 \\
\hline Algeria & 3 \\
\hline Egypt & 3 \\
\hline Iceland & 3 \\
\hline Lebanon & 3 \\
\hline Tunisia & 3 \\
\hline Brunei Darussalam & 2 \\
\hline Iraq & 2 \\
\hline Malta & 2 \\
\hline Mauritius & 2 \\
\hline Morocco & 2 \\
\hline Senegal & 2 \\
\hline Sudan & 2 \\
\hline Syrian Arab Republic & 2 \\
\hline Tanzania & 2 \\
\hline Ukraine & 2 \\
\hline Venezuela & 2 \\
\hline American Samoa & 1 \\
\hline Armenia & 1 \\
\hline Benin & 1 \\
\hline Bosnia and Herzegovina & 1 \\
\hline Cote d'Ivoire & 1 \\
\hline Dominican Republic & 1 \\
\hline Georgia & 1 \\
\hline Greenland & 1 \\
\hline Jamaica & 1 \\
\hline Lesotho & 1 \\
\hline Liberia & 1 \\
\hline Liechtenstein & 1 \\
\hline Macedonia & 1 \\
\hline Myanmar & 1 \\
\hline Namibia & 1 \\
\hline Nepal & 1 \\
\hline Panama & 1 \\
\hline Puerto Rico & 1 \\
\hline Rwanda & 1 \\
\hline Uruguay & 1 \\
\hline Zimbabwe & 1 \\
\hline Undefined & 477 \\
\hline Total Articles & 7868 \\
\hline
\end{tabular}

Similarly, the analysis on the subject area has shown that almost 50\% of the articles published in this area of research is in the subject area of social science and business management. This is shown in the figure 2 which gives the subject wise breakup of the articled related to employability published and indexed in Scopus. Table 2 shows the breakup of the articles published in each of the subject area.

Table 2: Subject area wise breakup of articles indexed in Scopus related to employability

\begin{tabular}{|c|c|c|c|}
\hline $\begin{array}{r}\text { SUBJECT AREA } \\
\text { Social Sciences }\end{array}$ & $\begin{array}{c}\begin{array}{c}\text { No. of } \\
\text { articles }\end{array} \\
2475\end{array}$ & \multicolumn{2}{|c|}{$\begin{array}{c}\text { Lable 3: Number of articles indexed in Scopus related to } \\
\text { employability }\end{array}$} \\
\hline Medicine & 1367 & YEAR & No of Articles \\
\hline Business, Management and Accounting & 1039 & \multirow{3}{*}{\multicolumn{2}{|c|}{$\begin{array}{l}\text { Published By: } \\
\text { Blue Eyes Intelligence Engineering } \\
\& \text { Sciences Publication }\end{array}$}} \\
\hline Psychology & 467 & & \\
\hline $\begin{array}{l}\text { Retrieval Number: C12481083S219/2019๑BEIESP } \\
\text { DOI:10.35940/ijrte.C1248.1083S219 }\end{array}$ & 814 & & \\
\hline
\end{tabular}

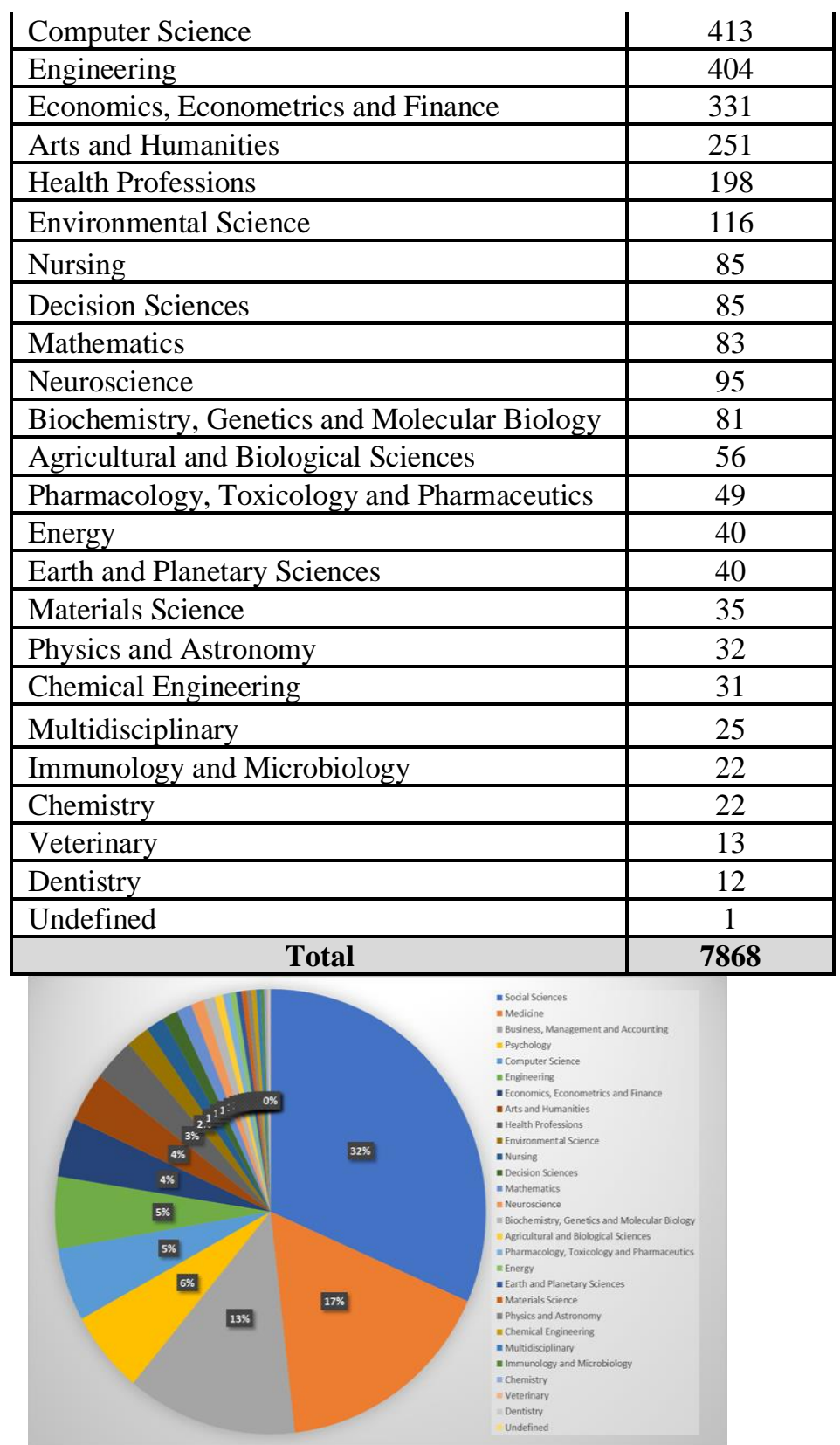

Figure 2: Subject area wise breakup of articles indexed in Scopus related to employability (1929 - 2018)

The breakup given in the table 2 clearly concludes that majority of the research area is under the subject of social sciences and business management. The analysis shows that topic is well researched in these subject areas. The third criteria used for the analysis is the number of articles published, the figure 3 shows the trend of the number of articles published related to employability, the trend shows there is a steady increase in the number of articles in this area. Table 3 shows the number of articles indexed in Scopus related to employability from the year 1929 to 2018. 
Graduate Employability in the Kingdom of Saudi Arabia: A future research Agenda

\begin{tabular}{|c|c|}
\hline YEAR & No of Articles \\
\hline 2018 & 953 \\
\hline 2017 & 869 \\
\hline 2016 & 727 \\
\hline 2015 & 702 \\
\hline 2014 & 696 \\
\hline 2013 & 452 \\
\hline 2012 & 346 \\
\hline 2011 & 338 \\
\hline 2010 & 259 \\
\hline 2009 & 227 \\
\hline 2008 & 192 \\
\hline 2007 & 174 \\
\hline 2006 & 135 \\
\hline 2005 & 174 \\
\hline 2004 & 126 \\
\hline 2003 & 145 \\
\hline 2002 & 119 \\
\hline 2001 & 109 \\
\hline 2000 & 110 \\
\hline 1999 & 87 \\
\hline 1998 & 70 \\
\hline 1997 & 65 \\
\hline 1996 & 49 \\
\hline 1995 & 39 \\
\hline 1994 & 31 \\
\hline 1993 & 23 \\
\hline 1992 & 21 \\
\hline 1991 & 24 \\
\hline 1990 & 26 \\
\hline 1989 & 35 \\
\hline 1988 & 29 \\
\hline 1987 & 29 \\
\hline 1986 & 22 \\
\hline 1985 & 23 \\
\hline 1984 & 13 \\
\hline 1983 & 10 \\
\hline 1982 & 28 \\
\hline 1981 & 30 \\
\hline 1980 & 23 \\
\hline 1979 & 20 \\
\hline 1978 & 15 \\
\hline 1977 & 23 \\
\hline 1976 & 26 \\
\hline 1975 & 72 \\
\hline 1974 & 59 \\
\hline 1973 & 41 \\
\hline 1972 & 13 \\
\hline 1971 & 5 \\
\hline 1970 & 8 \\
\hline 1969 & 7 \\
\hline 1968 & 4 \\
\hline 1967 & 2 \\
\hline 1966 & 6 \\
\hline 1965 & 4 \\
\hline 1964 & 1 \\
\hline 1963 & 5 \\
\hline 1962 & 2 \\
\hline 1961 & 3 \\
\hline
\end{tabular}

\begin{tabular}{|c|c|}
\hline YEAR & No of Articles \\
\hline 1959 & 1 \\
\hline 1958 & 2 \\
\hline 1956 & 1 \\
\hline 1954 & 1 \\
\hline 1953 & 1 \\
\hline 1952 & 1 \\
\hline 1951 & 4 \\
\hline 1950 & 2 \\
\hline 1946 & 1 \\
\hline 1945 & 2 \\
\hline 1944 & 1 \\
\hline 1942 & 2 \\
\hline 1939 & 1 \\
\hline 1936 & 1 \\
\hline 1929 & 1 \\
\hline Total & $\mathbf{7 8 6 8}$ \\
\hline
\end{tabular}

Although there is an increase in the number of articles published every year, the study focused on the graduate employability in KSA is scarce. There were about 953 articles published in this area in the year 2018, however majority of these articles published are from the western countries.

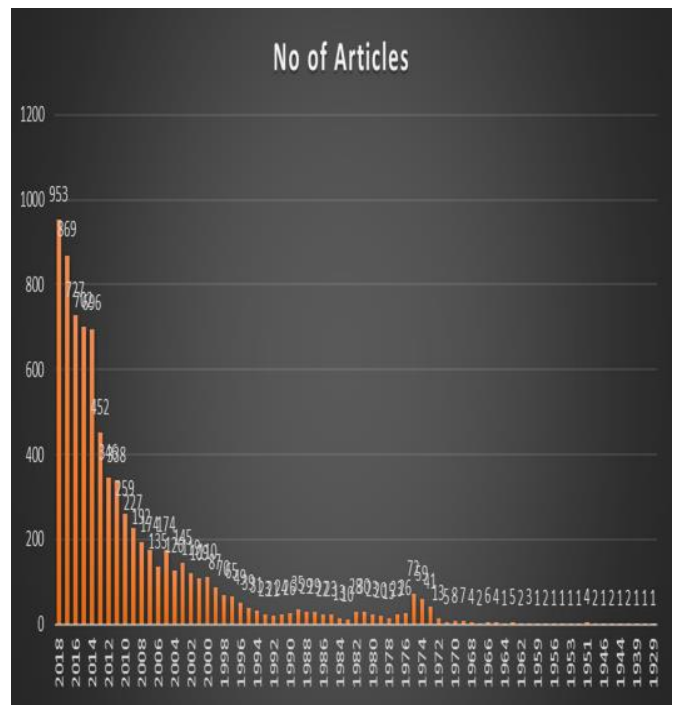

Figure 3: Number of articles indexed in Scopus related to employability

The summary of these three analyses has clearly shown that there is a need to explore the employability of the graduates in KSA. In the next stage further analysis was conducted on the 16 articles where the study was conducted in KSA, this is to understand the gap in the literature in the studies on employability. The analysis on the research on employability had shown that the first article was published in the year 2011 and this area of research came into prominence recently. However, out of these 16 articles only 12 articles were related to employability and the other 4 articles were either not related or it was conducted by a author from KSA but the sample used for the study was not from KSA [12]-[16]. Table 4 shows the details of these articles in this area of research [17]-[22].

Table 3: Summary of articles indexed in Scopus

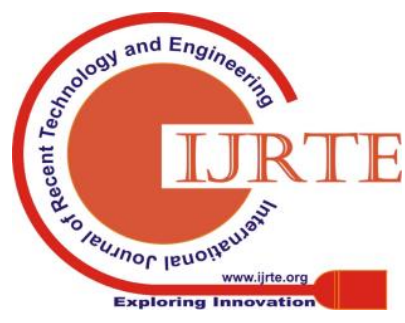


related to employability in $\mathrm{KSA}$

\begin{tabular}{|c|c|c|}
\hline Authors & Title & Year \\
\hline $\begin{array}{l}\text { Almutairi } \\
\text { M.M., Hasanat } \\
\text { M.H.A. }\end{array}$ & $\begin{array}{c}\text { Predicting the suitability of IS } \\
\text { students' skills for the recruitment in } \\
\text { Saudi Arabian industry }\end{array}$ & 2018 \\
\hline $\begin{array}{c}\text { Santhosh D., } \\
\text { Goverdhan C., } \\
\text { Sangam K., } \\
\text { Shailaja S., } \\
\text { Roopa G. }\end{array}$ & $\begin{array}{l}\text { Impact of english language teaching } \\
\text { in technical education }\end{array}$ & 2018 \\
\hline $\begin{array}{l}\text { Rizwan A., } \\
\text { Alsulami H., } \\
\text { Elnahas N., } \\
\text { Bashir M., } \\
\text { Bawareth F., } \\
\text { Kamrani R., } \\
\text { Noorelahi R. }\end{array}$ & $\begin{array}{l}\text { Impact of emotional intelligence on } \\
\text { the academic performance and } \\
\text { employability of female engineering } \\
\text { students in Saudi Arabia }\end{array}$ & 2018 \\
\hline Elgeddawy M. & $\begin{array}{l}\text { Impact of analyzing open online } \\
\text { educational video on university } \\
\text { students' academic performance }\end{array}$ & 2018 \\
\hline $\begin{array}{l}\text { Zaryab A., } \\
\text { Saeed U. }\end{array}$ & $\begin{array}{l}\text { Educating entrepreneurship: A tool to } \\
\text { promote self employability }\end{array}$ & 2018 \\
\hline Varshney D. & Expatriates Go, Let Us Grow & 2018 \\
\hline $\begin{array}{l}\text { Faridi M.R., } \\
\text { Ebad R. }\end{array}$ & $\begin{array}{l}\text { Transformation of higher education } \\
\text { sector through massive open online } \\
\text { courses in Saudi Arabia }\end{array}$ & 2018 \\
\hline $\begin{array}{l}\text { Rhodes A., } \\
\text { Danaher M.M., } \\
\text { Kranov A.A. }\end{array}$ & $\begin{array}{l}\text { Assessing students' foundation skills } \\
\text { prior to the STEM majors }\end{array}$ & 2017 \\
\hline Jamjoom Y. & $\begin{array}{l}\text { Private higher education and graduate } \\
\text { employability in Saudi Arabia }\end{array}$ & 2016 \\
\hline $\begin{array}{c}\text { Hadad G.E., } \\
\text { Naimieb Z., } \\
\text { Halili S.H., } \\
\text { Abuzaid R.A., } \\
\text { Siraj S. }\end{array}$ & $\begin{array}{l}\text { Integrating employability skills in } \\
\text { school curriculum }\end{array}$ & 2014 \\
\hline $\begin{array}{l}\text { Clementking } \\
\text { A., Muhammad } \\
\text { A. }\end{array}$ & $\begin{array}{c}\text { Technology based learning analysis } \\
\text { of CBCS model at KKU }\end{array}$ & 2013 \\
\hline
\end{tabular}

Majority of the studies in the research area of employability, used the quantitative method and they studies variables varied from one study to another. Some of the variables used and topics covered in these studies are soft skills, self-regulated learning (SRL), and academic achievement of students, Emotional intellegience, Acdemic performance, Discourse level, critical thinking, deep learning, and future employability, educational programs in developing the entrepreneurial intentions, changing labour market, government policies and employment, Massive Open Online Courses (MOOCs) and its paradigm shift towards open global education, General Education Foundation Skills Assessment (GEFSA), learner's suitability potential.

\section{V.DISCUSSION AND CONCLUSION}

we can see that most of the past literature has been focused on skills for employability indicators. In addition, some literature has suggested that over depending on skills only are not enough to promote employability especially with the current situation where jobs are less or even when there are jobs but there is a skill mismatch. However, the review of literature clearly highlighted that the factors contributing towards KSA graduate's employability is one underexplored area. The future research must be focused in this area. The future recommendation for research in this area would be the study on factors contributing to the employability with career strategies as a mediator.

\section{REFERENCES}

1. Green, F., \& Henseke, G. (2016). Should governments of OECD countries worry about graduate underemployment?. Oxford Review of Economic Policy, 32(4), 514-537.

2. Johnson, S., \& Burden, T. (2005). Young people, employability and the induction process. Joseph Rowntree Foundation, York, England.

3. Kolawole, C. O., \& Arikpo, P. A. (2004). Predictors of Self-Employment Efforts Among Unemployed Nigerian graduates.

4. Posner, R. A. (1999). The law and economics of the economic expert witness. Journal of Economic Perspectives, 13(2), 91-99.

5. Almunajjed, M. (2010). Women's employment in Saudi Arabia: A major challenge. Booz \& Co, 2-13.

6. Farhan, B., Brevetti, M., \& Laditan, D. (2016). Unemployment in Saudi Arabia: The ethical and economic impact of foreign workers on the Middle East market. Middle East Journal of Business, 55(3672), $1-18$.

7. Fakeeh, M. S. (2009). Saudization as a solution for unemployment: The case of Jeddah western region (Doctoral dissertation, University of Glasgow)

8. Callen, M. T., Cherif, R., Hasanov, F., Hegazy, M. A., \& Khandelwal, P. (2014). Economic diversification in the GCC: Past, present, and future. International Monetary Fund.

9. CDSI, 2012. Available from http://www.cdsi.org.sa/index.php.

10.Sanil, H. S., Ramakrishnan, S., Alwethainani, M., Kazi, A. G., \& Siddique, M. (2016). Effectiveness of supply chain management with reference to apparel industry: A case study in India. International Review of Management and Marketing, 6(4S), 176-184.

11.Ramakrishnan, S., Hishan, S. S., \& Kanjanapathy, M. (2016). Corporate Social Responsibility in Malaysian Apparel Manufacturing Industry: A Study on Corporate Social Responsibility Website Reporting. International Review of Management and Marketing, 6(4S), 205-208.

12.Almutairi, M. M., \& Hasanat, M. H. A. (2018, April). Predicting the suitability of IS students' skills for the recruitment in Saudi Arabian industry. In 2018 21st Saudi Computer Society National Computer Conference (NCC) (pp. 1-6). IEEE.

13.Santhosh, D., Goverdhan, C., Sangam, K., Shailaja, S., \& Roopa, G. (2018). Impact of English Language Teaching in Technical Education. Indian Journal of Public Health Research \& Development, 9(11).

14.Alsulami, H., Bashir, M., Rizwan, A., Elnahas, N., Bawareth, F., Noorelahi, R., \& Kamrani, R. (2019). Impact of emotional intelligence on the academicperformance and employability of female engineering students in Saudi Arabia. The International journal of engineering education, 35(1), 119-125.

15.Elgeddawy, M. (2018, November). Impact of Analyzing Open Online Educational Video on University Students' Academic Performance. In European Conference on e-Learning (pp. 726-730). Academic Conferences International Limited.

16.Zaryab, A., \& Saeed, U. (2018). Educating entrepreneurship: a tool to promote self employability. International Journal of Entrepreneurship and Small Business, 35(2), 143-161.

17.Varshney, D. (2018). Expatriates Go, Let Us Grow: An Analysis of Employment Patterns and Development of a Viable HRD Model of Saudi Arabia. African and Asian Studies, 17(4), 340-370.

18.Faridi, M. R., \& Ebad, R. (2018). Transformation of higher education sector through massive open online courses in Saudi Arabia. Problems and Perspectives in Management, 16(2), 220.

19.Rhodes, A., Danaher, M. M., \& Kranov, A. A. (2017). Assessing students' foundation skills prior to the STEM majors. Global Journal of Engineering Education, 19(3), 194-199.

20.Jamjoom, Y. (2016). Private higher education and graduate employability in Saudi Arabia. In A Global Perspective on Private Higher Education (pp. 189-204). Chandos Publishing.

21.El Hadad, G., Naimieb, Z., Halili, S. H., Abuzaid, R. A., \& Siraj, S. (2014). Integrating employability skills in school curriculum. MANAGEMENT AND TECHNOLOGY IN KNOWLEDGE, SERVICE, TOURISM AND HOSPITALITY, 59.

22.Clementking, A., Muhammad, A., Shah, A., \& Ahmad, F. (2013).

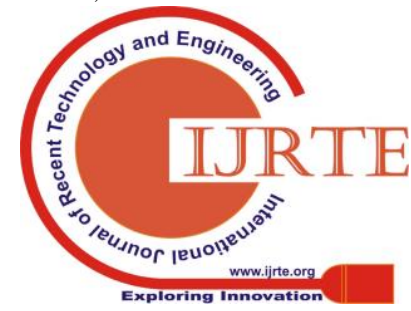


Graduate Employability in the Kingdom of Saudi Arabia: A future research Agenda

Technology Based Learning Analysis of CBCS Model at KKU. Int. J. Emerg. Technol. Learn, 8(3).

\section{AUTHORS PROFILE}

Mohammed Alwethainani, Faculty of Economics and Management, University Putra Malaysia. *Corresponding author's email: wathnani@yahoo.com

Zuraina Dato Mansor, Faculty of Economics and Management, University Putra Malaysia. 